\title{
Desarrollo morfológico e histológico del sistema reproductor de Pomacea patula catemacensis (Baker 1922) (Mollusca, Caenogastropoda: Ampullariidae)
}

\author{
Morphological and histological development of the reproductive system of Pomacea \\ patula catemacensis (Baker 1922) (Mollusca, Caenogastropoda: Ampullariidae)
}

\author{
LAURA CARREÓN-PALAU ${ }^{1}$, ESTHER URIA-GALICIA ${ }^{2}$, FÉLIX ESPINOSA-CHÁVEZ $^{3}$ \\ \& FERNANDO MARTÍNEZ-JERÓNIMO ${ }^{3 *}$
}

\author{
${ }^{1}$ Centro de Investigaciones Biológicas del Noroeste, La Paz, BCS, México \\ ${ }^{2}$ Laboratorio de Histología Animal. Escuela Nacional de Ciencias Biológicas, IPN Carpio esquina Plan de Ayala s/n, \\ Distrito Federal 11340, México \\ ${ }^{3}$ Laboratorio de Hidrobiología Experimental. Escuela Nacional de Ciencias Biológicas, \\ I.P.N. Carpio esquina Plan de Ayala s/n, Distrito Federal 11340, México; \\ *e-mail para correspondencia: ferjeronimo@hotmail.com
}

\begin{abstract}
RESUMEN
El "tegogolo" Pomacea patula catemacensis es un gasterópodo dulceacuícola comestible, endémico del Lago de Catemaco en Veracruz, México. En los últimos años las poblaciones naturales se han visto diezmadas debido a que su captura se realiza sin control, a lo que se suma el alto grado de deterioro ambiental que presenta el lago, producto del "azolvamiento", así como por la contaminación por plaguicidas y detergentes. El objetivo del presente estudio fue caracterizar histológica y morfológicamente el sistema reproductor de $P$. patula catemacensis y determinar las etapas de madurez gonádica en condiciones de laboratorio. Se determinó que la maduración depende de la talla y no de la edad de los organismos, y se identificaron cuatro etapas principales en el desarrollo de machos y hembras: Los estadios y sus longitudes promedio ( \pm intervalo de confianza del $95 \%$ ) son (1) inmadura o indiferenciada (talla de 0,72 a $7 \mathrm{~mm}$ ), (2) maduración temprana $(18,95 \pm 1,96 \mathrm{~mm})$, (3) maduración intermedia $(29,29 \pm 4,9 \mathrm{~mm})$ y (4) madurez total $(35,89 \pm 3,92 \mathrm{~mm})$. En este molusco los sexos están separados, la fertilización es interna y el desarrollo es ovíparo. En las hembras la secreción de albúmina y de carbonato de calcio se realiza en la glándula de la albúmina, característica en la que difiere de otras especies como $P$. paludosa y $P$. canaliculata, las cuales poseen además glándula de la cápsula. Es posible identificar el grado de madurez de los caracoles utilizando criterios anatómicos visuales, como la glándula de la albúmina, en el caso de la hembra, y el órgano copulador en el macho.
\end{abstract}

Palabras clave: "tegogolo", histología, anatomía, reproducción, Lago de Catemaco.

\section{ABSTRACT}

The "apple snail" Pomacea patula catemacensis is an edible freshwater mollusc, endemic to the Catemaco Lake in Veracruz, Mexico. During the past few years, the natural populations of this species have been depleted mainly by uncontrolled fishery, and because of environmental degradation and pollution by pesticides and detergents. In the present study, we carried out the histological and morphological characterization of the reproductive system of $P$. patula catemacensis under laboratory conditions. We found that the reproductive development of this snail depended more on the size than on the age the animals, and identified four development main stages, both for males and females. The main stages and their mean lengths ( \pm confidence interval at $95 \%$ ) were (1) immature or not differenced (from 0.72 to $7 \mathrm{~mm}$ ), (2) early maturation (from $18.95 \pm 1.96 \mathrm{~mm}$ ), (3) intermediate maturation (from $29.29 \pm 4.9 \mathrm{~mm}$ ), and (4) full maturity (from $35.89 \pm 3.92 \mathrm{~mm}$ ). This species is oviparous, both sexes are separated, and fertilization is internal. Albumin and calcium carbonate secretion in females are performed through the albumin gland, a trait that distinguishes this species from others, such as P. paludosa and P. canaliculata. The stage of development can be identified by means of using anatomical traits, such as the albumin gland (in the case of females), or the intromittent organ (in males).

Key words: apple snail, histology, anatomy, reproduction, Catemaco lake. 


\section{INTRODUCCIÓN}

El "tegogolo" Pomacea patula catemacensis es un gasterópodo dulceacuícola comestible, endémico del Lago de Catemaco en Veracruz, México, localidad en la que ocupa el cuarto lugar de importancia en la producción pesquera (Naranjo-García \& García-Cubas 1985, González-Soriano et al. 1997).

En los últimos años su captura ha descendido drásticamente ya que pasó de más de 5.000 ton en el periodo de 1980 a 1989 , a solo 24 ton en el año 2001 (CONAPESCA 2001, datos no publicados). Esta disminución está asociada a una captura sin control y al grado de deterioro ambiental que presenta el lago, sobre todo por el "azolvamiento", resultado del arrastre de sedimentos de las áreas taladas aledañas, así como por la contaminación por plaguicidas y detergentes (González-Soriano et al. 1997).

En virtud de la importancia de esta especie, se justifican plenamente los esfuerzos realizados para lograr su conservación como recurso, y su producción controlada mediante técnicas de acuacultura. Estas iniciativas, sin embargo, se ven limitadas en sus alcances debido a la carencia de información biológica básica y de tipo ecológico sobre esta especie. Se considera que el conocimiento de la biología reproductiva es fundamental como primer paso en cualquier iniciativa de tipo biotecnológico y de regulación pesquera. La escasa información disponible a este respecto, indica que el "tegogolo" tiene potencial para ser cultivado, ya que presenta altos porcentajes de eclosión $(83 \%$ en condiciones de laboratorio y $90 \%$ en el medio natural), dos a tres desoves en periodos de 30 días, y fecundidad de hasta 218 huevos por hembra, en condiciones de laboratorio, y 245 en el campo, a lo que se suma su desarrollo directo y un corto período de incubación (Osorio-Santamaría \& García-García 1986).

La anatomía del sistema reproductor en especies como Pomacea haustrum, $P$. lineata y $P$. canaliculata de Brasil (Lopes 1955, 1956a, 1956b) y P. flagellata de México (Rangel-Ruiz 1987) ya ha sido descrito. También se cuenta con la caracterización histológica del sistema reproductor de $P$. canaliculata y una breve descripción de su desarrollo a partir de la eclosión (Andrews 1964).

Por su parte, Vermeire \& Hinsch (1984) y Hinsch \& Vermeire (1990a, 1990b) realizaron el estudio de la ultraestructura e histoquímica del sistema reproductor de $P$. paludosa con énfasis particular sobre la glándula de la albúmina y de la cápsula. No obstante estos antecedentes, hasta el momento no se han realizado estudios anatómicos ni histológicos o de las etapas de madurez gonádica en $P$. patula catemacensis.

En función de lo anterior, en el presente estudio se realizó la caracterización del sistema reproductor de machos y hembras y se determinaron las etapas de madurez gonádica en condiciones de laboratorio, mediante el seguimiento del desarrollo del sistema reproductor a partir de organismos recién eclosionados, lográndose también la definición de la edad-talla del inicio de la madurez gonádica.

\section{MATERIALES Y MÉTODOS}

Se recolectaron masas ovígeras de $P$. patula catemacensis en la margen oriente del Lago de Catemaco, y fueron transportadas al Laboratorio de Hidrobiología Experimental, ENCB-IPN en recipientes de plástico con una base de algodón humedecido, dentro de un contenedor térmico para mantener condiciones adecuadas de temperatura y humedad. En el laboratorio se incubaron las puestas a $30{ }^{\circ} \mathrm{C}$ y $75 \%$ de humedad relativa, en recipientes de $50 \mathrm{~L}$ acondicionados como cámaras húmedas. Los juveniles obtenidos entre los 0 y 6 días después de la eclosión se distribuyeron al azar en 6 acuarios de $40 \mathrm{~L}$, acoplados a un filtro biológico de tezontle diseñado por Espinosa-Chávez et al. (1992), en densidad de 100 individuos por acuario. Los caracoles se mantuvieron a temperatura ambiental de $26,9{ }^{\circ} \mathrm{C}$ (con una variación de \pm 2 $\left.{ }^{\circ} \mathrm{C}\right), \mathrm{pH}$ de 8,5 y concentración promedio de oxígeno de 4,95 $\mathrm{mg} \mathrm{L}^{-1}$. Como alimento se empleó una mezcla gelificada de la microalga Scenedesmus incrassatulus $(60 \%)$ y alimento balanceado para trucha (40\%, ración de engorda Purina ${ }^{\circledR}$ "trucha finalizador", con $40 \%$ de proteína y $10 \%$ de grasas), suministrado ad libitum. Las microalgas fueron cultivadas en bolsas de polietileno de $40 \mathrm{~L}$ según el método sugerido por Martínez-Jerónimo \& EspinosaChávez (1994), empleando el medio mineral Basal de Bold (Stein 1973). La mezcla de microalgas y alimento balanceado fue gelificada adicionando almidón de maíz al $8 \%$ y elevando rápidamente la temperatura a $75^{\circ} \mathrm{C}$ en un horno de microondas para posteriormente enfriar a 4 ${ }^{\circ} \mathrm{C}$. El gel así obtenido fue suministrado a los moluscos en láminas de $3 \times 3 \times 0,5 \mathrm{~cm}$.

Mensualmente se registraron la talla (en $\mathrm{mm}$, medida desde el ápice de la columela hasta el extremo opuesto) y el peso húmedo (drenado, en g) de todos los individuos en experimentación. Para el estudio histológico se separó una muestra de 10 organismos indiferenciados de 0 y 1 mes de edad, y de dos hem- 
bras y dos machos durante cada uno de los siguientes 6 meses. Los ejemplares completos se fijaron durante $48 \mathrm{~h}$ en líquido de Bouin; después de este tiempo se les retiró la concha, cortándola alrededor de la columela y hasta la base del opérculo, y se procedió a eliminar el fijador mediante lavados con alcohol de $70^{\circ}$, lo cual se realizó continuamente hasta que el alcohol quedó transparente. Los ejemplares completos fueron procesados para su análisis microscópico mediante la técnica histológica de inclusión en parafina, obteniéndose cortes seriados, transversales y longitudinales, de 8 $\mathrm{mm}$ de grosor, en un micrótomo rotatorio de parafina marca Leica. Los cortes obtenidos se tiñeron con las técnicas de tinción de Hematoxilina-Eosina, Tricrómica de Masson y de Sylven. Las laminillas se analizaron y fotografiaron con un microscopio Leica ATC2000 y cámara fotográfica MPS30.

Las observaciones sobre la maduración de los organismos se dieron por concluidas al registrarse la primera oviposición, situación que indicó que los organismos habían alcanzado la madurez gonádica.

\section{RESULTADOS}

Se pudo corroborar que $P$. patula catemacensis es una especie dioica, la fertilización es interna y su desarrollo es ovíparo. Se identificaron cuatro etapas bien diferenciadas en el proceso de la maduración gonádica, tanto en el sistema reproductor masculino como en el femenino: inmadura o indiferenciada, maduración temprana, maduración intermedia y madurez completa.

\section{Inmadura o indiferenciada}

En esta etapa no es posible distinguir anatómicamente a las hembras de los machos, aunque histológicamente se distinguen las células germinales, que se han diferenciado durante el desarrollo embrionario. Después de la eclosión (0 a 6 días de edad y $1 \mathrm{~mm}$ de longitud) se observaron dichas células con núcleo y escaso citoplasma ligeramente basófilo, formando grupos compactos, ubicados en la zona donde se desarrollará la gónada (Fig. 1A). En el primer mes $(4,52 \pm 2,5 \mathrm{~mm})$ y segundo mes $(9 \pm 1,92 \mathrm{~mm})$ las células están separados por tejido conjuntivo y ocupan más espacio, el núcleo presenta cromatina más laxa y el citoplasma es abundante y acidófilo. Estas células se extienden a lo largo de la orilla de la espira en el vértice interno del cuerpo del caracol pegado a la columela, formando cordones compactos separados por tejido conjuntivo laxo (Fig. 1B). Los otros componentes del sistema reproductor aún no son evidentes.
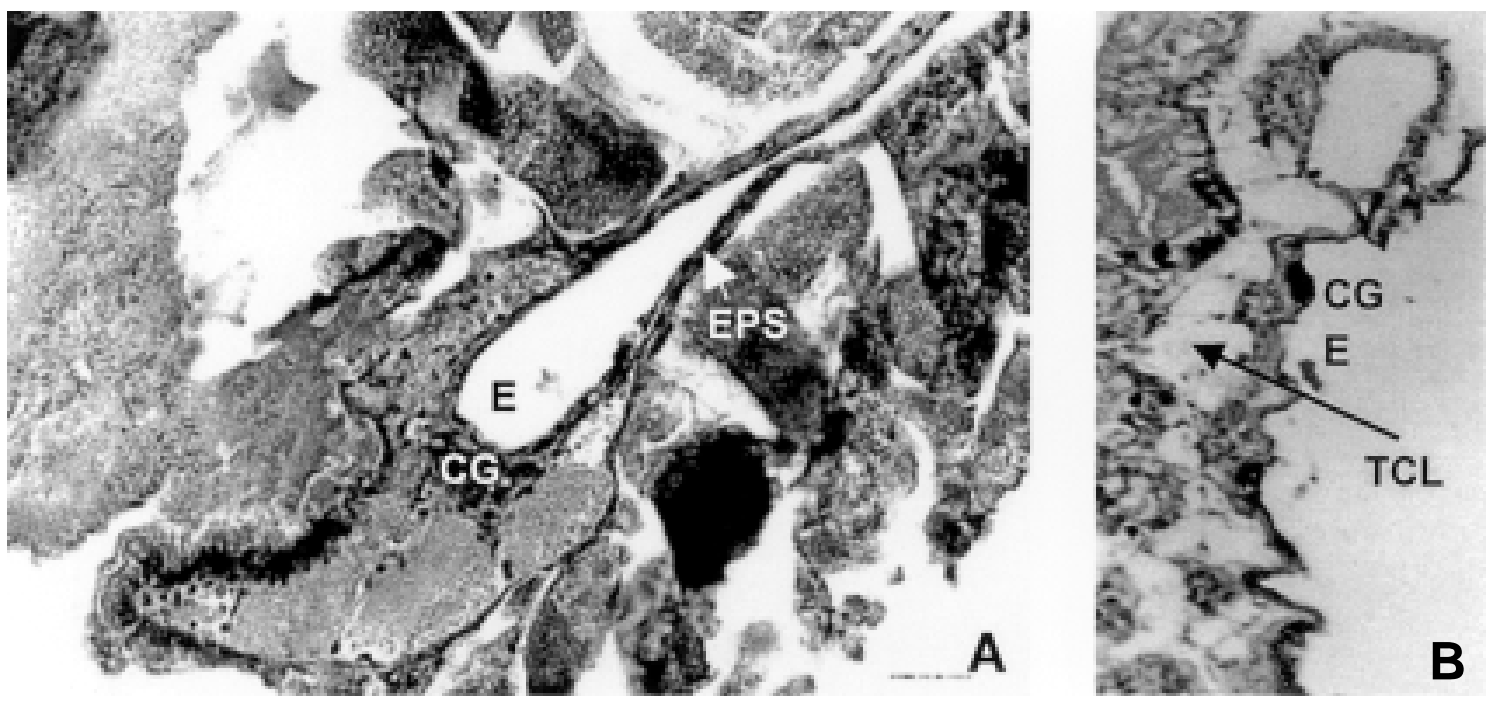

Fig. 1: Sistema reproductor indiferenciado de Pomacea patula catemacensis. (A) Células germinales (CG) en la base de la espira (E), la cual está cubierta por epitelio plano simple (EPS); H-E, 20x; (B) células germinales (CG) en la parte interna de la espira (E) y tejido conjuntivo laxo (TCL); H-E 20x.

Undifferentiated reproductive system of Pomacea patula catemacensis. (A) Germ cells (CG) in the base of the spire (E), which is covered with simple squamous epithelium (EPS); H-E, 20x; (B) germ cells (CG) in to the internal side of the spire (E), and loose connective tissue (TCL); H-E 20x. 


\section{Maduración temprana}

Durante el tercer mes tampoco se pueden distinguir anatómicamente ambos sexos, pero sí histológicamente, ya que presentan estructuras que permiten diferenciar a los machos de las hembras, como los túbulos seminíferos en los machos y las ovogonias en las hembras (Fig. 5A, 10A y 10B).

\section{Maduración intermedia}

En esta etapa se distinguen anatómicamente algunos órganos del aparato reproductor, aunque no son funcionales. Histológicamente ya se han formado las gónadas tanto de las hembras como de los machos (Fig. 6 y 10).

\section{Madurez total}

Esta etapa se alcanza cuando todos los órganos del sistema reproductor son funcionales para lograr la primera reproducción y obtener la primera oviposición. La glándula de la albúmina, de color naranja, en el caso de la hembra, y el órgano copulador del macho, que en esta etapa presenta una coloración rosa brillante, permiten diferenciarlos anatómicamente (Fig. 3D y 9A).

\section{Anatomía del sistema reproductor masculino}

El sistema reproductor masculino se localiza en la parte derecha de la cavidad del manto, junto a la branquia, y se extiende desde el pene hasta el testículo, localizado en la zona interna de la espira del cuerpo del caracol, rodeando la columela de la concha.

En los organismos maduros se distingue claramente el órgano copulador, un pliegue muscular de color amarillo que es una prolongación especializada del manto y que ayuda al pene durante la copulación; generalmente se encuentra plegado y su función es abrir el gonoporo femenino. Cerca de la base del órgano copulador sobresale el pene, un tubo delgado protegido en su porción distal por un pliegue que se prolonga del manto y que en su porción proximal se encuentra enrollado dentro de un saco formando la vaina del pene. El sistema reproductor masculino presenta un conducto principal o deferente, que va desde el pene hasta el testículo.

Al salir el conducto deferente del testículo, se constriñe y queda inmerso en la masa visceral, posteriormente penetra en la próstata, la cual en su porción anterior se adelgaza y hacia la parte posterior se ensancha formando un lóbulo, y desemboca en el pene (Fig. 2 y 3D).

\section{Caracterización histológica del sistema repro- ductor masculino}

El órgano copulador está constituido por tejido conjuntivo denso irregular y abundantes haces de fibras musculares lisas, que se distribuyen en diferentes sentidos; presenta senos que contienen hemolinfa y el epitelio que lo recubre es

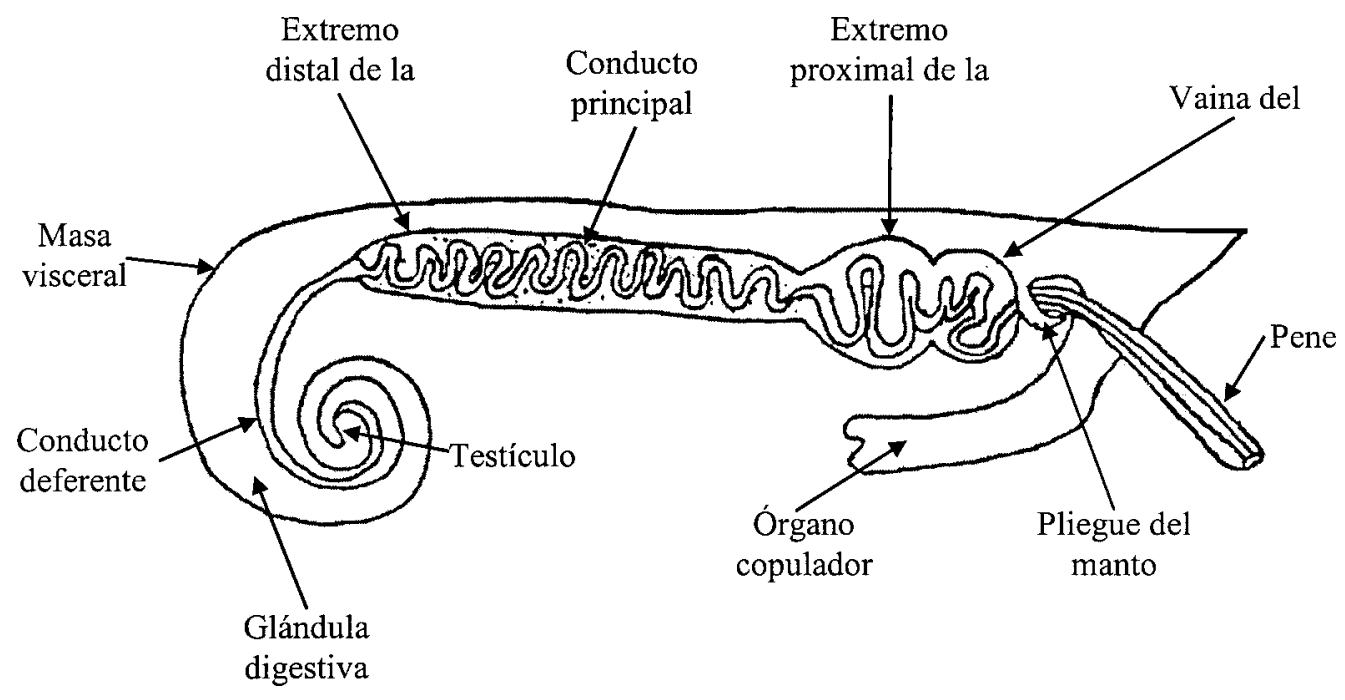

Fig. 2: Esquema anatómico del sistema reproductor masculino de P. patula catemacensis en corte longitudinal.

Anatomical scheme of the male reproductive system of $P$. patula catemacensis in longitudinal view. 

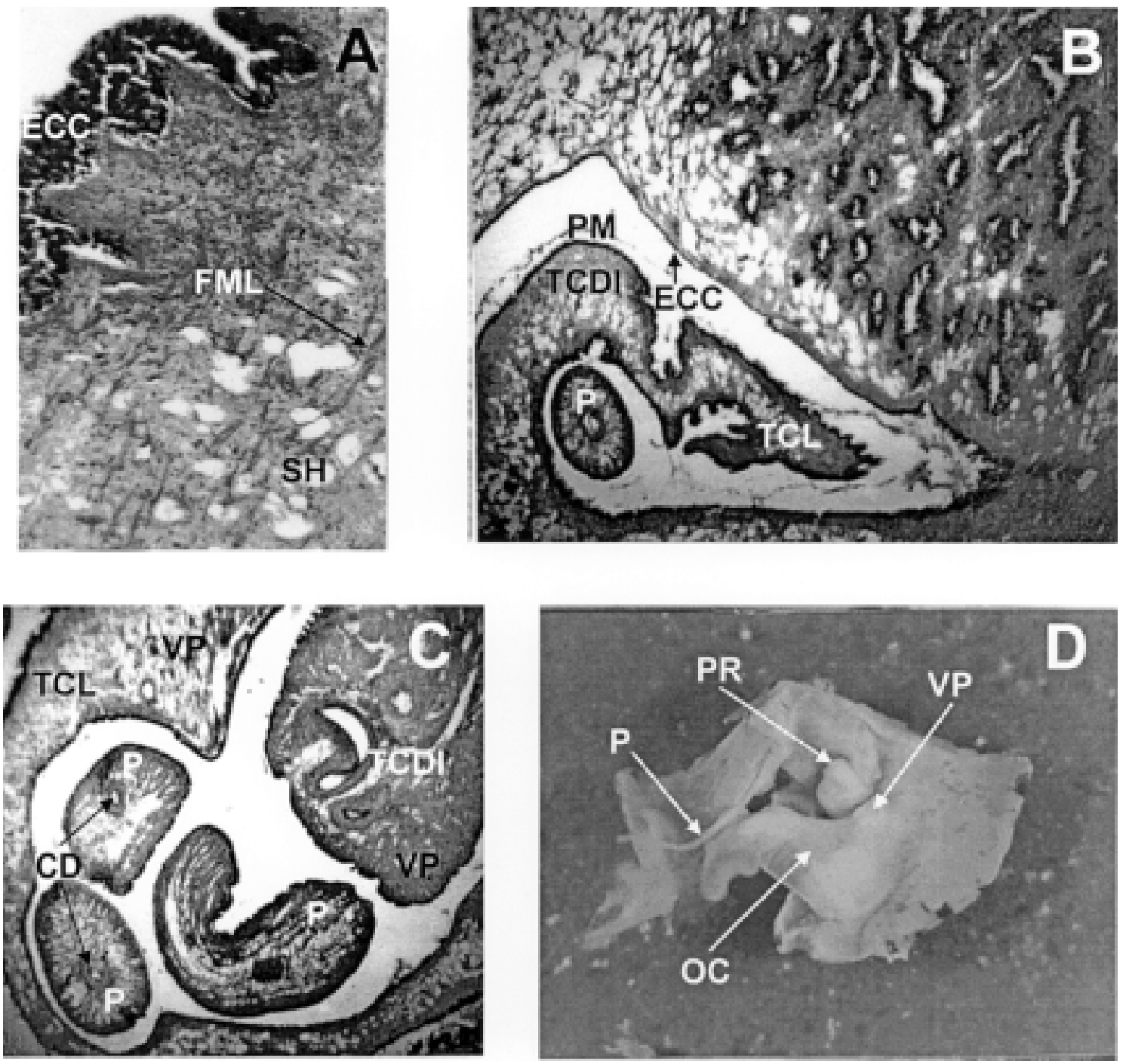

Fig. 3: Sistema reproductor masculino de P. patula catemacensis. (A) Órgano copulador con fibras musculares lisas (FML), epitelio cilíndrico simple ciliado (ECC) y senos con hemolinfa (SH); H-E, 20x. (B) Pliegue del manto (PM), epitelio cilíndrico simple ciliado (ECC), pene (P), tejido conjuntivo laxo (TCL) y denso irregular (TCDI); H-E, 20x. (C) Vaina del pene (VP) y pene enrollado sobre sí mismo (P), conducto deferente (CD), tejido conjuntivo laxo (TCL) y tejido conjuntivo denso irregular (TCDI); H-E, 20x. (D) Órgano copulador (OC), vaina del pene (VP) y parte anterior de la próstata $(\mathrm{PR})$ en su base; el pene $(\mathrm{P})$ está extendido.

Male reproductive system of $P$. patula catemacensis. (A) Copulative organ with smooth muscular cells (FML), simple ciliated columnar epithelium (ECC) and sinuses with haemolymph (SH); H-E, 20x. (B) Mantle fold (PM), simple ciliated columnar epithelium (ECC), penis (P), connective loose tissue (TCL), and irregular dense connective tissue (TCDI); H-E, 20x. (C) Sheath of penis (VP) and penis (P), ductus deferens (CD), connective loose tissue (TCL) and irregular dense connective tissue (TCDI); H-E, 20x. (D) Copulative organ (OC), sheath of penis (VP) and, in its base, the anterior portion of the prostate $(\mathrm{PR})$; the penis $(\mathrm{P})$ is extended.

cilíndrico simple ciliado (Fig. 3A). El manto forma una pequeña prolongación que rodea la parte apical del pene cuando no está extendido, por lo que se le denominó como pliegue del manto. Esta prolongación presenta tejido conjuntivo laxo con haces de fibras musculares li- sas aisladas, abundantes senos con hemolinfa, se encuentra rodeado por una capa de tejido conjuntivo denso irregular sobre la que se encuentra epitelio cilíndrico simple ciliado, que contiene abundantes glándulas unicelulares mucosas intercaladas que la recubren (Fig. 3B). 
La vaina del pene está cubierta por epitelio cilíndrico simple ciliado además de glándulas unicelulares mucosas, y contiene gran cantidad de tejido conjuntivo laxo. El pene es un tubo que se enrolla en sí mismo y que contiene en su centro al conducto deferente, que comunica a la próstata con el pene; este tiene una gran luz con epitelio cilíndrico simple ciliado rodeado por tejido conjuntivo denso irregular, una capa de músculo liso, escasas fibras musculares aisladas y senos con hemolinfa. Hacia el exterior, el pene presenta tejido conjuntivo laxo con abundantes senos que por su irrigación contribuyen a darle firmeza durante la cópula (Fig. 3C). El epitelio que lo recubre externamente es cilíndrico simple con abundantes células glandulares acidófilas y basófilas intercaladas entre este. Una vista general del aparato reproductor masculino se muestra en las Fig. 2 y 3D.
La próstata es una glándula mucosa cuyo conducto principal está recubierto por epitelio cilíndrico simple ciliado, alrededor de este desembocan los conductos de numerosos adenómeros formados por células glandulares que contienen abundantes gránulos acidófilos y están rodeadas por tejido conjuntivo (Fig. 4A). Histológicamente las porciones anterior y posterior de la próstata, aunque tienen la misma función glandular, se diferencian porque la primera está recubierta por tejido conjuntivo denso irregular, además hay un notable desarrollo de los conductos y los adenómeros ensanchan la glándula, mientras que en la segunda porción la glándula es más delgada, porque hay menos adenómeros rodeados por tejido conjuntivo laxo (Fig. 4B y 4C).

El conducto deferente se comunica directamente con el testículo, el cual se encuentra
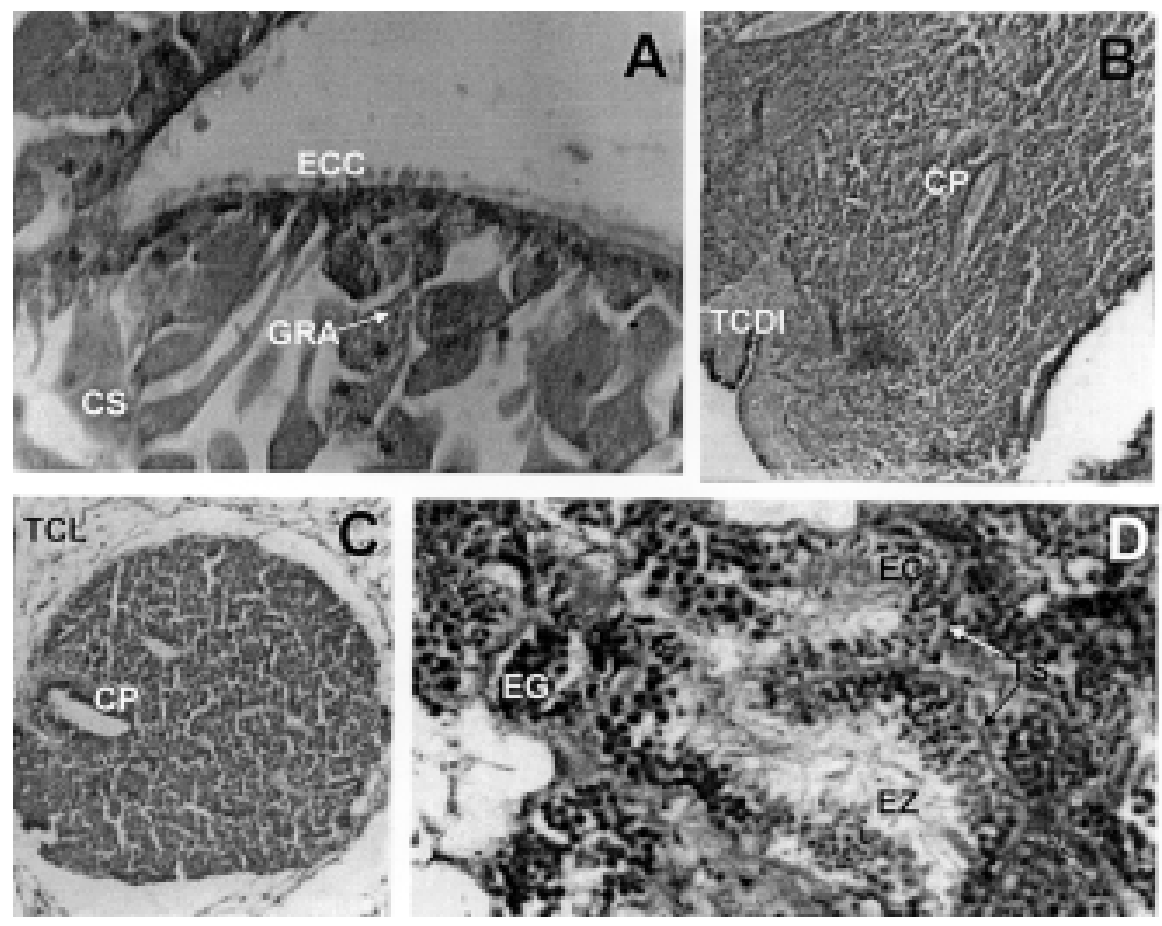

Fig. 4: Sistema reproductor masculino de P. patula catemacensis. (A) Próstata: células secretoras (CS) con gránulos acidófilos (GRA), sus conductos desembocan al conducto principal cubierto por epitelio cilíndrico simple ciliado (ECC); H-E, 40x. (B) Región anterior de la próstata mostrando tejido conjuntivo denso irregular que la recubre (TCDI) y el conducto principal lleno de secreción (CP); HE, 20x. (C) Región posterior de la próstata inmersa en el tejido conjuntivo laxo (TCL); el conducto principal esta vacío (CP), H-E, 20x. (D) Testículo con túbulos seminíferos (TS) conteniendo a los espermatozoides (EZ), espermatogonias (EG) y espermatocitos secundarios (EC); H-E, 20x.

Male reproductive system of $P$. patula catemacensis. (A) Prostate: secretory cells (CS) with acidophilic granules (GRA), their ducts lead to the principal duct, lined with simple ciliated columnar epithelium (ECC); H-E, 40x. (B) Anterior section of the prostate lined with dense irregular connective tissue (TCDI), the main duct is filled with secreted substances (CP); H-E, 20x. (C) Posterior part of the prostate embedded in loose connective tissue (TCL); the main duct is empty (CP); H-E, 20x. (D) Testis with seminiferous tubules (TS), spermatozoids (EZ), spermatogonia (EG) and secondary spermatocytes (EC); H-E, 20x. 
separado de la glándula digestiva por tejido conjuntivo laxo y solo ocupa las dos primeras vueltas de la espira del cuerpo del caracol, junto a la parte interna de la columela de la concha. En esta zona hay gran cantidad de células pigmentarias en el tegumento, dándole una coloración más intensa que en la hembra. El testículo está formado por numerosos túbulos seminíferos irregulares separados por escasas fibras colágenas y tejido conjuntivo laxo; en su pared se encuentran las células gametogénicas en diferentes etapas de madurez (espermatogonias, espermatocitos y espermatozoides), rodeados por las células de Sertoli, que separan entre sí a cada uno de los grupos del mismo tipo celular (Fig. 4D).

\section{Etapas de maduración gonádica del macho}

Maduración temprana: Durante el tercer mes $(18,95 \pm 1,95 \mathrm{~mm})$ los túbulos seminíferos del testículo solo contienen espermatogonias que descansan sobre la membrana basal. El núcleo tiene la cromatina condensada y el citoplasma es ligeramente basófilo (Fig. 5A). El testículo se localiza entre el tejido conjuntivo laxo y limita con la glándula digestiva (Fig. 5B). Se puede identificar el conducto deferente, que comunicará a la gónada con la próstata y a esta con el pene; este se extiende a lo largo del manto, pero aún no desemboca en el primordio de la vaina del pene (Fig. 5C). El primordio de la vaina del pene se nota como una evaginación del manto formada solo por tejido conjuntivo denso irregular y cubierto por epitelio cilíndrico simple pigmentado (Fig. 5D).

Maduración intermedia: Durante el cuarto mes $(29,29 \pm 4,89 \mathrm{~mm})$ el testículo presenta un mayor desarrollo entre el tejido conjuntivo laxo y el epitelio que colinda con la columela de la concha. En los túbulos seminíferos son evidentes los diferentes tipos de células, predominando las espermatogonias y los espermatocitos, con escasos espermátides y espermatozoides (Fig. 6A y 6B). El conducto deferente se enrolla en sí mismo y queda rodeado por el tejido glandular de la próstata; no se aprecian diferencias entre la región anterior y posterior (Fig. 6C). Durante este mes también es evidente el conducto deferente en la zona de comunicación entre la próstata y el pene, el cual presenta un epitelio cilíndrico simple ciliado.

También se desarrolla la abertura del pene al llegar el conducto al primordio de la vaina del pene (Fig. 6D), este crece y se enrolla, dando la impresión de ser mas de un conducto (Fig. 6E). El conducto deferente del pene presenta un epitelio cilíndrico simple ciliado ro- deado por una capa de fibras colágenas, tejido conjuntivo laxo con gran cantidad de senos y externamente epitelio cilíndrico simple pigmentado. De la misma manera, la vaina del pene se ve claramente separada y está constituida por tejido denso irregular y la rodea epitelio cilíndrico simple, entre el que se localizan algunas células glandulares (Fig. 6E). Durante el cuarto mes se distingue el pliegue, como una prolongación del manto que envuelve el extremo distal del pene. El tejido es conjuntivo con fibras musculares lisas aisladas y abundantes senos, está rodeado de epitelio cilíndrico simple ciliado con numerosas células glandulares de secreción basófila intercaladas entre este (Fig. 3B). Durante el quinto mes $(31,5 \pm 1,05 \mathrm{~mm})$ se identifica el órgano copulador (Fig. 3D).

Madurez total: A los seis meses $(38 \pm 3,56$ $\mathrm{mm})$ se alcanza la madurez gonádica total al registrarse la primera oviposición. Anatómicamente es muy evidente el órgano copulador de color rosa, lo que permite distinguir fácilmente a los machos (Fig. 3D). En esta etapa la gónada ocupa la tercera parte de la espira del cuerpo del caracol, la proporción de tejido conjuntivo disminuye claramente. En los túbulos seminíferos del testículo se localizan todos los tipos celulares: espermatogonias, espermatocitos primarios y secundarios, espermatides y en mayor proporción espermatozoides (Fig. 4D).

Las dos porciones de la próstata ya tienen una clara función secretora, el conducto deferente presenta secreción en la luz, los adenómeros aumentan en número y las células que los constituyen tienen abundantes gránulos acidófilos, la cantidad de secreción aumenta y su acumulación es mayor en la porción anterior, lo que puede explicar su ensanchamiento (Fig. 4A, 4B y 4C).

La vaina del pene tiene la misma organización estructural pero todos los elementos han aumentado de tamaño al igual que el órgano copulador. El pene se acomoda detrás de este órgano, protegido por el pliegue del manto (Fig. 3B), de tal manera que al entrar el órgano copulador en el gonoporo femenino le abre paso al pene y permite su entrada hasta la bolsa copulatriz, dentro de la glándula de la albúmina.

Los últimos órganos que se desarrollaron son el pliegue del manto en el cuarto mes y el órgano copulador en el quinto. Por lo antes mencionado, la gónada solo se puede identificar histológicamente a partir del tercer mes de edad. En la Tabla 1 se resumen las etapas de madurez gonádica de los machos analizados en el estudio histológico presentado. 

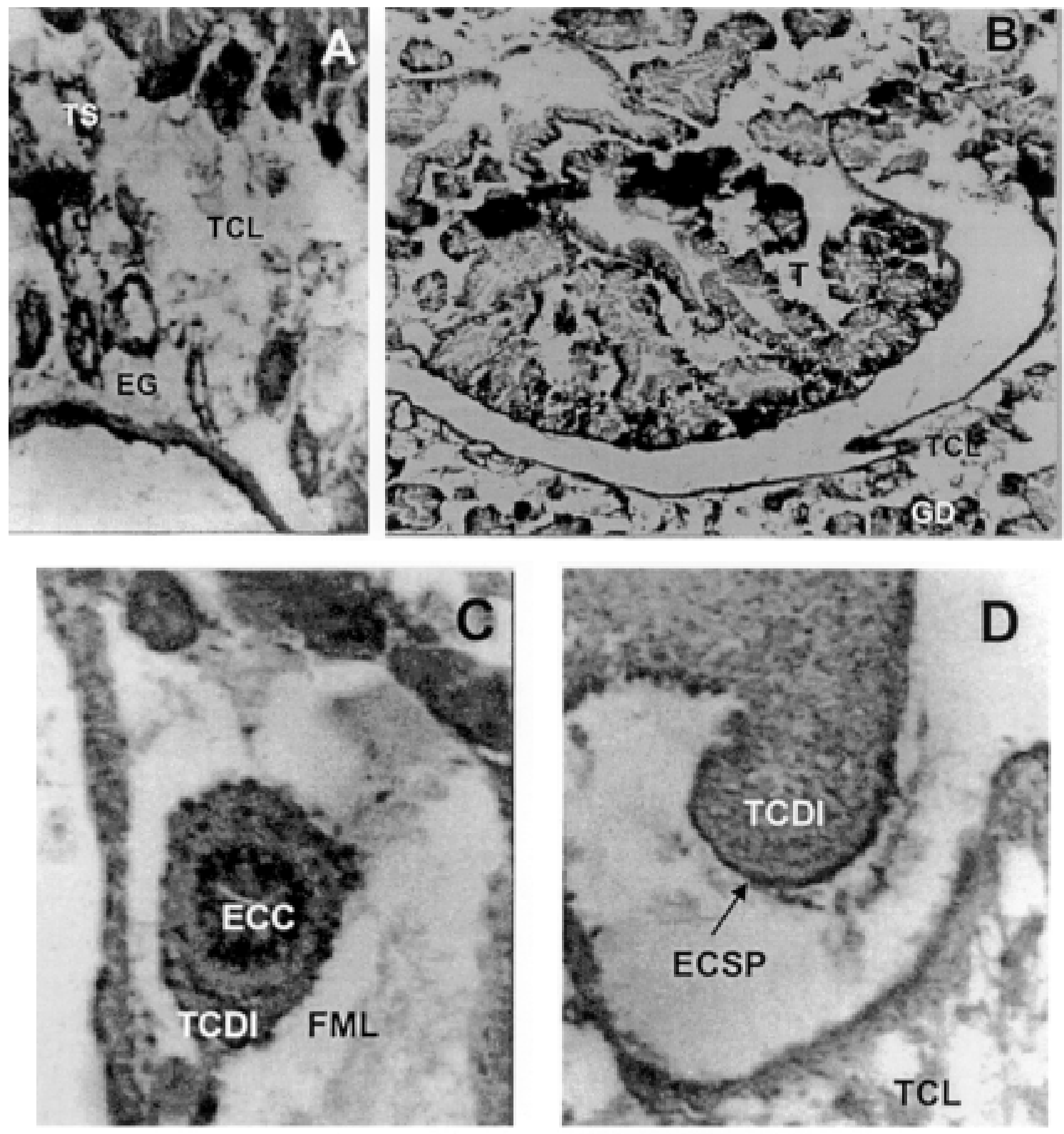

Fig. 5: Sistema reproductor masculino de P. patula catemacensis. Etapa de maduración temprana. (A) El testículo solo contiene espermatogonias (EG), entre el tejido conjuntivo laxo (TCL) se observan los túbulos seminíferos (TS); H-E, 20x. (B) Testículo (T) rodeado por tejido conjuntivo laxo (TCL), limitado por la glándula digestiva (GD); H-E 10x. (C) Conducto deferente en corte transversal formado por epitelio cilíndrico simple ciliado (ECC), fibras musculares lisas (FML) y tejido conjuntivo denso irregular (TCDI); H-E, 40x. (D) Evaginación del manto que inicia la formación de la vaina del pene, compuesta por tejido conjuntivo denso irregular (TCDI) y tejido conjuntivo laxo (TCL), y cubierta por epitelio cilíndrico simple pigmentado (ECSP). Corte longitudinal; H-E, 20x.

Male reproductive system of $P$. patula catemacensis. Stage of early maturation. A. The testis has only spermatogonia (EG), the seminiferous tubules (TS) are embedded in loose connective tissue (TCL); H-E 20x. (B) Testis (T) surrounded by loose connective tissue (TCL), and limited for the digestive gland (GD); H-E, 10x. (C) Ductus deferens in transversal cut; simple ciliated columnar epithelium (ECC), smooth muscular cells (FML) and dense irregular connective tissue (TCDI); H-E, 40x. (D) Mantle evagination that begins the formation of the penis sheath, composed by dense irregular connective tissue (TCDI) and loose connective tissue (TCL), and covered with simple ciliated pigmented columnar epithelium (ECSP). Longitudinal cut. H-E, 20x. 

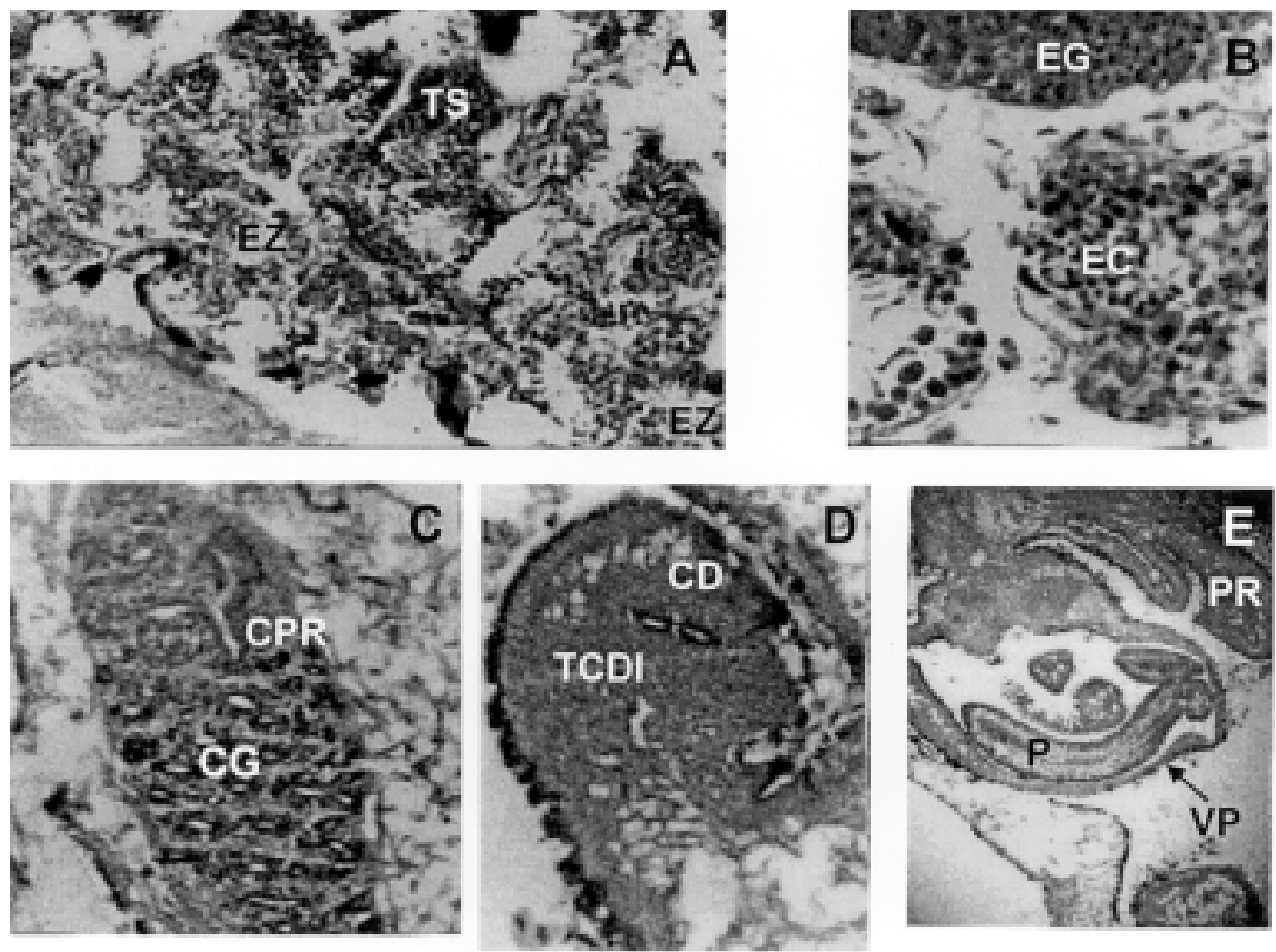

Fig. 6: Sistema reproductor masculino de $P$. patula catemacensis en etapa de maduración intermedia. (A y B) Testículo con túbulos seminíferos (TS), espermatozoides (EZ), espermatogonias (EG) y espermatocitos (EC); H-E A, 20x; B, 40x. (C) Zona posterior de la próstata con su conducto (CPR) y células glandulares (CG); H-E 10x. (D y E) Proceso de desarrollo del pene. El conducto deferente (CD) invade el tejido conjuntivo denso irregular (TCDI) de la vaina del pene. En las últimas etapas, el pene (P) se ha diferenciado completamente dentro de la vaina del pene (VP) junto a la zona anterior de la próstata (PR); H-E D, 20x; E 10x.

Male reproductive system of $P$. patula catemacensis in the intermediate maturation stage. (A and B) Testis with seminiferous tubules (TS), spermatozoids (EZ), spermatogonia (EG) and spermatocites (EC); H-E, A; 20x, and B, 40x. (C) Posterior part of the prostate with its conduct (CPR) and glandular cells (CG); H-E, 10x. (D and E) Process of the penis development. The ductus deferens (CD) invades the dense irregular connective tissue (TCDI) of the penis sheath. In the last phases, the penis (P) looks completely differentiated inside the penis sheath (VP), aside with the anterior part of the prostate (PR); H-E, D, 20x, and E, 10x.

TABLA 1

Edad, peso y talla correspondientes a las etapas de madurez gonádica de machos de Pomacea patula catemacensis identificadas en el estudio histológico.

Valores promedio e intervalos de confianza $(95 \%)$

Age, weight and size corresponding to the stages of gonadic maturity, established in the histological study of males of Pomacea patula catemacensis. Average values and confidence intervals (95\%)

\begin{tabular}{crrl}
\hline $\begin{array}{c}\text { Edad } \\
\text { (meses })\end{array}$ & \multicolumn{1}{c}{$\begin{array}{c}\text { Peso } \\
(\mathrm{g})\end{array}$} & \multicolumn{1}{c}{$\begin{array}{c}\text { Talla } \\
(\mathrm{mm})\end{array}$} & \multicolumn{1}{c}{ Etapa de madurez } \\
\hline 0 & $0,0075 \pm 0,0001$ & $1 \pm 0,28$ & Inmadura o indiferenciada \\
1 & $0,11 \pm 0,0051$ & $4,52 \pm 2,5$ & $\begin{array}{l}\text { Inmadura o indiferenciada } \\
2\end{array}$ \\
3 & $0,185 \pm 0,0498$ & $9 \pm 1,92$ & Inmadura o indiferenciada \\
4 & $1,29 \pm 0,22$ & $18,95 \pm 1,95$ & Maduración temprana \\
5 & $1,91 \pm 0,208$ & $29,29 \pm 4,89$ & Maduración intermedia \\
6 & $6,4 \pm 1,04$ & $31,5 \pm 1,05$ & Maduración intermedia \\
\hline
\end{tabular}




\section{Anatomía del sistema reproductor femenino}

El sistema reproductor femenino se localiza en la parte derecha de la cavidad del manto junto a la branquia y se extiende desde el gonoporo hasta el ovario, localizado en la zona interna de la espira del cuerpo del caracol. Al igual que en el macho, el sistema reproductor femenino es una estructura continua que va desde el ovario hasta el gonoporo, este último se localiza junto al ano, de tal manera que el oviducto corre paralelo al recto y llega al receptáculo seminal donde se enrolla antes de entrar en la glándula de la albúmina; esta es ovoide y de color naranja brillante con una capa anterior amarilla y constituye la estructura más evidente del sistema reproductor femenino. De la región posterior de la glándula sale el oviducto que se une al ovario, el cual en las hembras maduras queda rodeado por la glándula digestiva (Fig. 7 y 8A).
Caracterización histológica del sistema reproductor femenino

El ovario es un cordón localizado dentro de la masa visceral en el vértice interno del borde de la espira del cuerpo del caracol, está inmerso en tejido conjuntivo laxo y crece rodeado por la glándula digestiva. El epitelio germinativo da origen a las ovogonias que se localizan sobre la membrana basal, estas se diferencian en ovocitos primarios y secundarios, los cuales están rodeados por células foliculares. A continuación del epitelio se encuentra una capa muy delgada de tejido conjuntivo denso irregular. El tegumento que rodea a la hembra en esta región presenta células pigmentarias escasas (Fig. 8B). El oviducto está revestido por epitelio cilíndrico ciliado, que descansa sobre la membrana basal y está rodeado por tejido conjuntivo laxo (Fig. 8C). Los adenómeros de la glándula de la

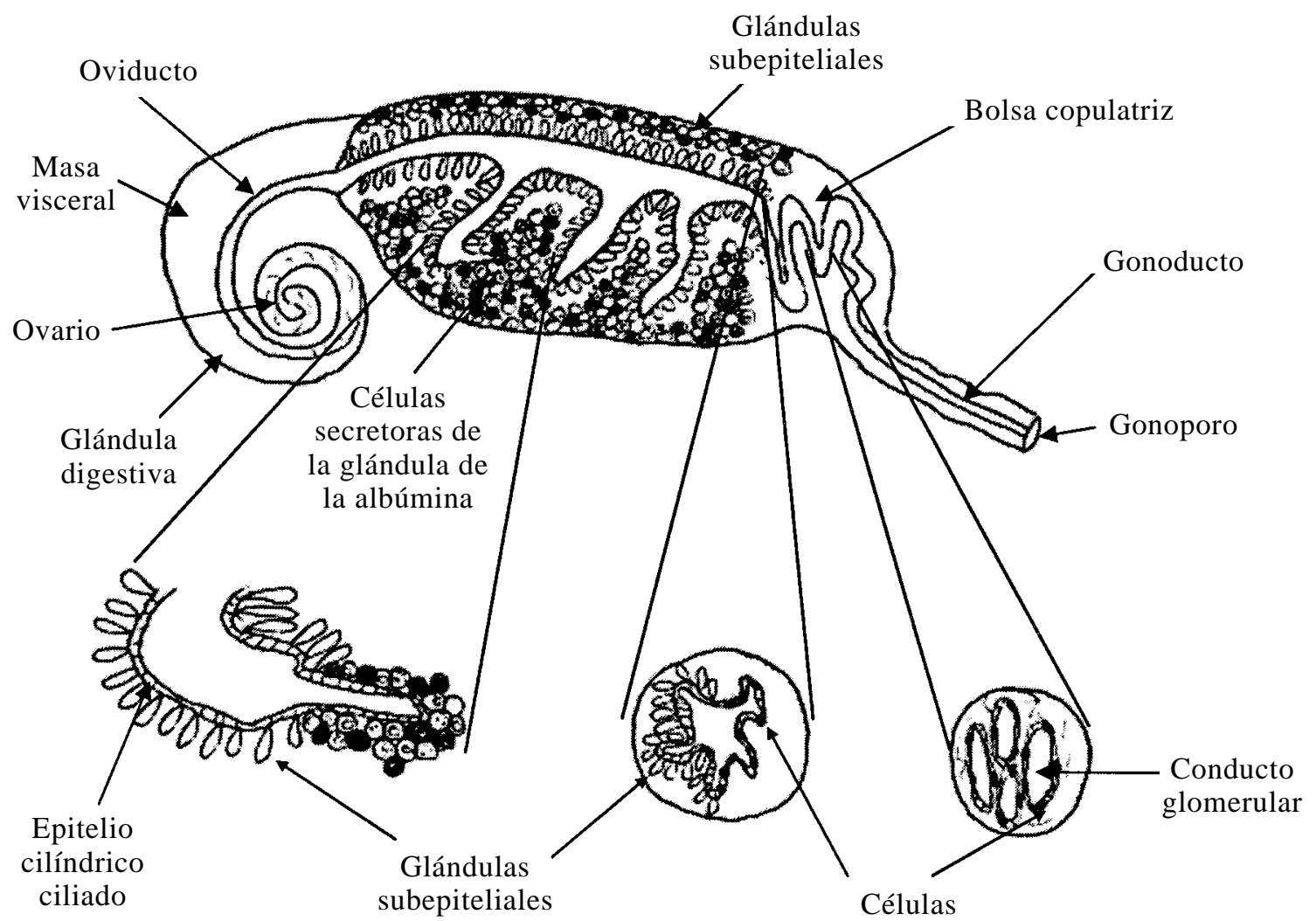

Fig. 7: Esquema anatómico del sistema reproductor femenino de P. patula catemacensis en corte longitudinal.

Anatomical scheme of the female reproductive system of $P$. patula catemacensis in longitudinal view. 

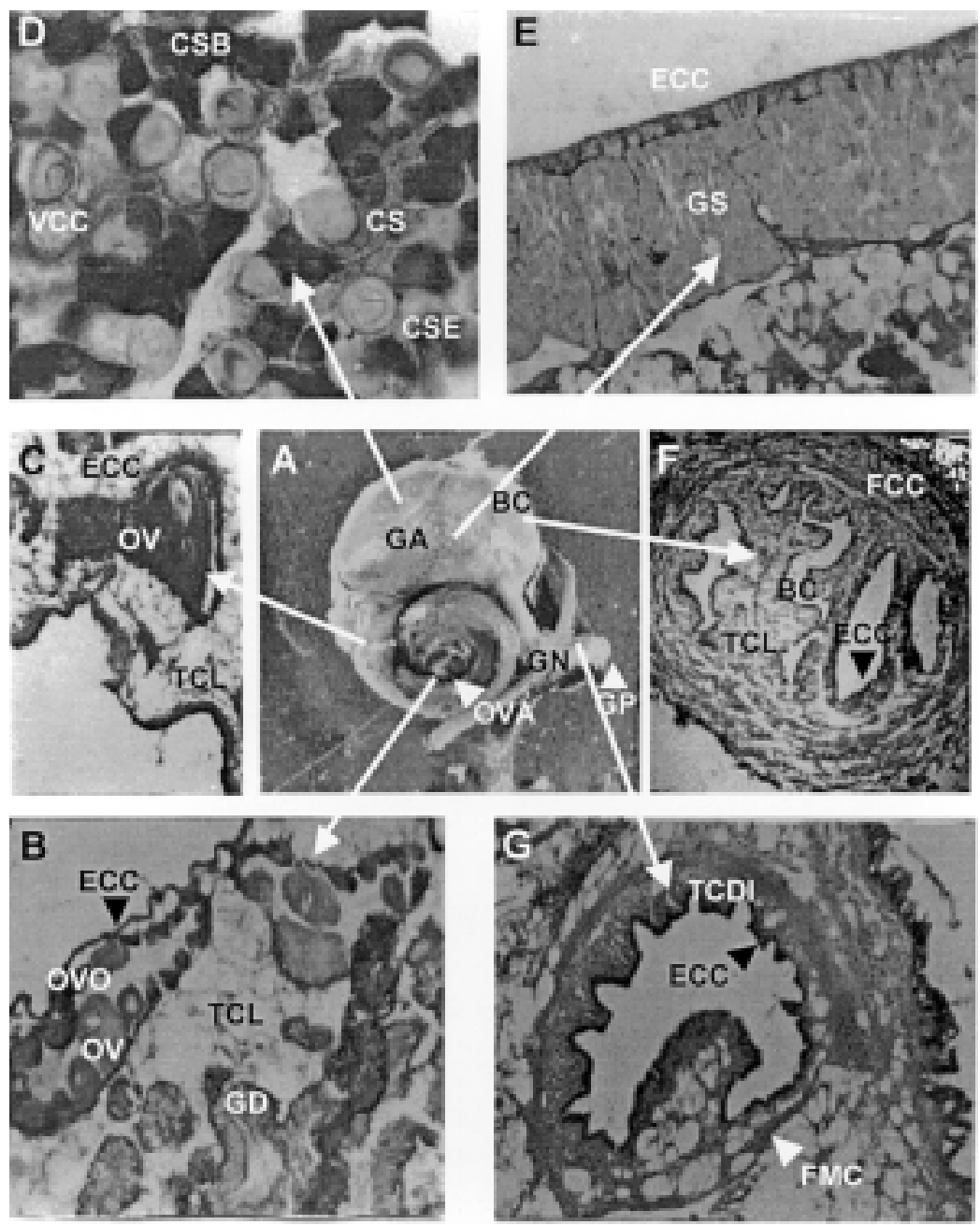

Fig. 8: Sistema reproductor femenino de P. patula catemacensis. (A) Ovario en la zona interna de la espira (OVA), la glándula de la albúmina (GA) es la más evidente; inmersa en esta se encuentra la bolsa copulatriz (BC), la cual desemboca al gonoporo (GP) a través del gonoducto (GN). (B) Ovario con ovocitos maduros (OV) y algunas ovogonias (OVO) abajo del epitelio cilíndrico ciliado (ECC); tejido conjuntivo laxo junto a la glándula digestiva (GD); H-E, 20x. (C) Oviducto con ovocitos (OV) que obliteran la luz. El epitelio que lo recubre es cilíndrico simple ciliado (ECC), y está rodeado por tejido conjuntivo laxo (TCL); H-E, 20x. (D) Glándula de la albúmina. Células secretoras basófilas (CSB), eosinofilas (CSE) y células con vesículas de carbonato de calcio (VCC), conducto secundario (CS); H-E, 40x. (E) Conducto principal de la glándula de la albúmina con células glandulares subepiteliales (GS) y epitelio cilíndrico simple ciliado (ECC). Técnica Tricrómica de Massón, 20x. (F) Bolsa copulatriz (BC) rodeada por fibras colágenas circulares (FCC) y tejido conjuntivo laxo (TCL); el conducto principal está revestido por epitelio cilíndrico simple ciliado (ECC). H-E, 10x. (G) Gonoporo. Conducto revestido de epitelio cilíndrico simple ciliado (ECC) rodeado de tejido conjuntivo denso irregular (TCDI) y fibras musculares circulares (FMC); H-E, 20x.

Female reproductive system of $P$. patula catemacensis. (A) Ovary in the internal part of the spire (OVA), the albumen gland (GA) is evident and the bursa copulatrix (BC) is immersed in it. The albumen gland leads into the gonopore (GP) through the gonoduct (GN). (B) Ovary with mature oocytes (OV) and some oogonia (OVO) below the ciliated columnar epithelium (ECC), surrounded for loose connective tissue, aside the digestive gland (GD); H-E, 20x. (C) Oviduct with oocytes (OV) that fill up the duct; this is covered with simple ciliated columnar epithelium (ECC), and is embedded in loose connective tissue (TCL); H-E, 20x. (D) Albumen gland. Basophilic (CSB) and eosinophilic secretor cells (CSE), and cells containing calcium carbonate vesicles (VCC), secondary conduct (CS); H-E, 40 x. (E) Main conduct of the albumen gland with subepithelial cell glands (GS), and simple ciliated columnar epithelium (ECC). Masson's trichromic technique, 20x. (F) Bursa copulatrix (BC) surrounded for circular collagen fibers (FCC) and loose connective tissue (TCL); the main duct is lined with simple ciliated columnar epithelium (ECC); H-E, 10x. (G) Gonopore. Conduct lined with simple ciliated columnar epithelium (ECC), surrounded for dense irregular connective tissue (TCDI) and circular muscular cells (FMC); H-E, 20x. 
albúmina están formados por tres tipos de células: el primero corresponde a las que secretan la albúmina, que son eosinófilas, con citoplasma homogéneo y algunas con gránulos de secreción; el segundo tipo es hialino con núcleo excéntrico y contienen vesículas con carbonato de calcio en cantidad variable; el tercer tipo es de células basófilas con gran cantidad de gránulos de secreción proteica. Esta glándula contiene abundantes conductos secundarios y senos (Fig. 8D). El conducto principal de la glándula de la albúmina se prolonga formando ciegos cuya luz también está revestida por epitelio cilíndrico ciliado y en algunas zonas presenta glándulas subepiteliales mucosas basófilas que contienen mucopolisacáridos sulfatados, y que son metacromáticas con la técnica de Sylven (Fig. 8E); en otras zonas se encuentra en contacto directo con los adenómeros propios de la glándula de la albúmina. El conducto principal de la glándula de la albúmina se modifica en la zona anterior, donde aumentan los pliegues y disminuye el tamaño de las glándulas subepiteliales; conforme se acerca a la bolsa copulatriz, pierde las glándulas subepiteliales y presenta una capa muscular delgada rodeada por tejido conjuntivo laxo (Fig. 8F). Finalmente presenta células caliciformes entre las células ciliadas del epitelio, formando un conducto glomerular de paredes delgadas, donde probablemente se lleve a cabo la fecundación (Fig. 7). El oviducto está revestido con el mismo epitelio, pero rodeado de tejido conjuntivo denso irregular y fibras musculares circulares, que forman una capa alrededor de este, manteniendo la misma estructura hasta el gonoporo (Fig. 8G).

\section{Etapas de maduración gonádica de la hembra}

Maduración temprana: Para el tercer mes $(18,95 \pm 1,95 \mathrm{~mm})$ el ovario alargado aumenta claramente su diámetro, la luz es evidente y solo se observan ovogonias con citoplasma intensamente basófilo, lo cual no permite distinguir con precisión al núcleo. Rodeando al ovario se encuentra una capa gruesa de fibras colágenas y a continuación hay tejido conjuntivo laxo que lo separa de la glándula digestiva, por un lado y del epitelio del manto por el otro (Fig. 9A y 9B). En esta etapa solo se distingue el oviducto sin variaciones a todo lo largo del manto, este está revestido por epitelio cilíndrico simple rodeado por tejido conjuntivo denso irregular que se continúa con el tejido conjuntivo laxo del manto. El arreglo histológico es semejante para el gonoporo y el oviducto (Fig. 9C). Se inicia la formación de la glándula de la albúmina, la cual contiene principalmente ade- nómeros con escasas células acidófilas y abundante tejido laxo entre ellas, con numerosos senos conteniendo hemolinfa (Fig. 9D).

Maduración intermedia: Durante el cuarto mes $(29,29 \pm 4,89 \mathrm{~mm})$ hay ovocitos primarios y secundarios. En el quinto mes $(31,5 \pm 1,2 \mathrm{~mm})$ el ovario aumenta de tamaño (Fig. 10A y 10B). La glándula de la albúmina aumenta también considerablemente en relación con el cuarto mes y está formada por adenómeros con células basófilas de citoplasma granular y acidófilas de citoplasma homogéneo; el tejido conjuntivo que las separa es escaso. Se presentan células con vesículas de carbonato de calcio en baja proporción. El oviducto tiene epitelio cilíndrico simple ciliado y descansa sobre una capa gruesa de fibras colágenas que lo separan de los adenómeros (Fig. 8D). En la porción anterior de la glándula de la albúmina se inicia el desarrollo de las glándulas subepiteliales en el conducto principal (Fig. 8E). La bolsa copulatriz es evidente y está revestida con epitelio cilíndrico simple ciliado con algunas células caliciformes entre el epitelio (Fig. 10C). El oviducto continúa creciendo, aumenta su luz y se forman pliegues hacia el interior (Fig. 10D).

Madurez total: esta etapa se alcanza a los seis meses de edad $(33,5 \pm 3,92 \mathrm{~mm})$ y se caracteriza por el considerable crecimiento del ovario y la mayor proporción de ovocitos en desarrollo (Fig. 8B). El oviducto presenta restos de ovocitos en su luz y gran cantidad de secreción probablemente proveniente del citoplasma celular o de las células foliculares (Fig. 8C). La glándula de la albúmina presenta un color naranja característico, las células basófilas muestran gran actividad al aumentar los gránulos de secreción, en las células aumenta la cantidad de vesículas de carbonato de calcio, las glándulas subepiteliales dan reacción positiva con la técnica tricrómica de Masson (coloración azulosa, correspondiente a una secreción proteica) (Fig. 8D y 8E). El tamaño de la bolsa copulatriz también aumenta considerablemente, sin modificar su estructura histológica (Fig. 11A). El gonoporo presenta pliegues característicos, aunque histológicamente es igual al oviducto (Fig. 11B).

La Tabla 2 resume las etapas de madurez gonádica de las hembras identificadas en el estudio histológico.

\section{DISCUSIÓN}

Mucho se ha discutido sobre la identidad taxonómica del "tegogolo", ya que de acuerdo a Bequaert \& Pain (citado en Rangel-Ruiz 1987) en 
México solo se encontraría la especie Pomacea flagellata. No obstante, esta especie presenta diferencias notables con $P$. patula catemacensis, entre otras en el aparato reproductor masculino, ya que la primera presenta una vaina del pene (Rangel-Ruiz 1987), a diferencia del "te- gogolo" que presenta una vaina y un pliegue del manto en la base del órgano copulador; dicho pliegue no tiene una función de vaina ya que no tiene el canal del pene ni lo rodea. Ocurre algo semejante con respecto a $P$. canaliculata, especie que fue caracterizada histológica-
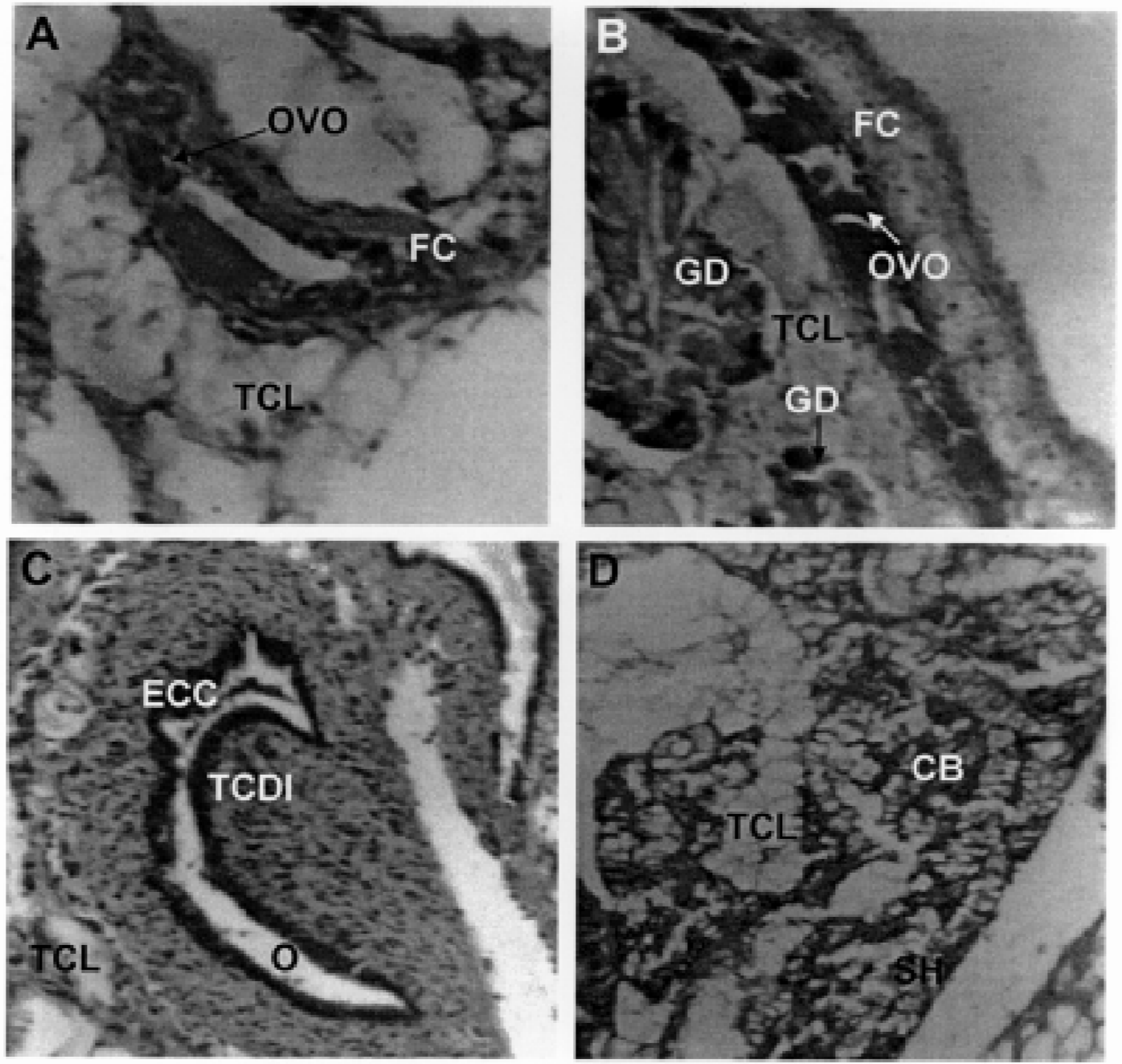

Fig. 9: Sistema reproductor femenino de $P$. patula catemacensis en etapa de maduración temprana. (A) Ovario en corte transversal con ovogonias (OVO), fibras de colágena (FC) y tejido conjuntivo laxo (TCL); H-E, 40x. (B) Ovario en corte longitudinal entre el tejido conjuntivo laxo (TCL) junto a la glándula digestiva (GD). Ovogonias (OVO) y fibras de colágena (FC); H-E, 20x. (C) Oviducto (O) no diferenciado cubierto por epitelio cilíndrico simple ciliado (ECC), tejido conjuntivo denso irregular (TCDI) entre el tejido conjuntivo laxo (TCL) del manto; H-E, 20x. (D) Tejido precursor de la glándula de la albúmina con células basófilas (CB) y abundante tejido conjuntivo laxo (TCL); senos de hemolinfa ( $\mathrm{SH})$; H-E, 20x.

Female reproductive system of $P$. patula catemacensis in early maturation stage. (A) Ovary in transversal cut, with oogonia (OVO), collagen fibers (FC) and loose connective tissue (TCL); H-E, 40x. (B) Ovary in longitudinal cut embedded in loose connective tissue (TCL), aside the digestive gland (GD). Oogonia (OVO) and collagen fibers (FC); H-E, 20x. (C) Undifferentiated oviduct $(\mathrm{O})$, lined with simple ciliated columnar epithelium (ECC), dense irregular connective tissue (TCDI) inside the mantle loose connective tissue (TCL). H-E, 20x. (D) Precursor tissue of the albumen gland, with basophilic cells (CB) and abundant loose connective tissue (TCL); sinuses with haemolymph (SH); H-E, 20x. 

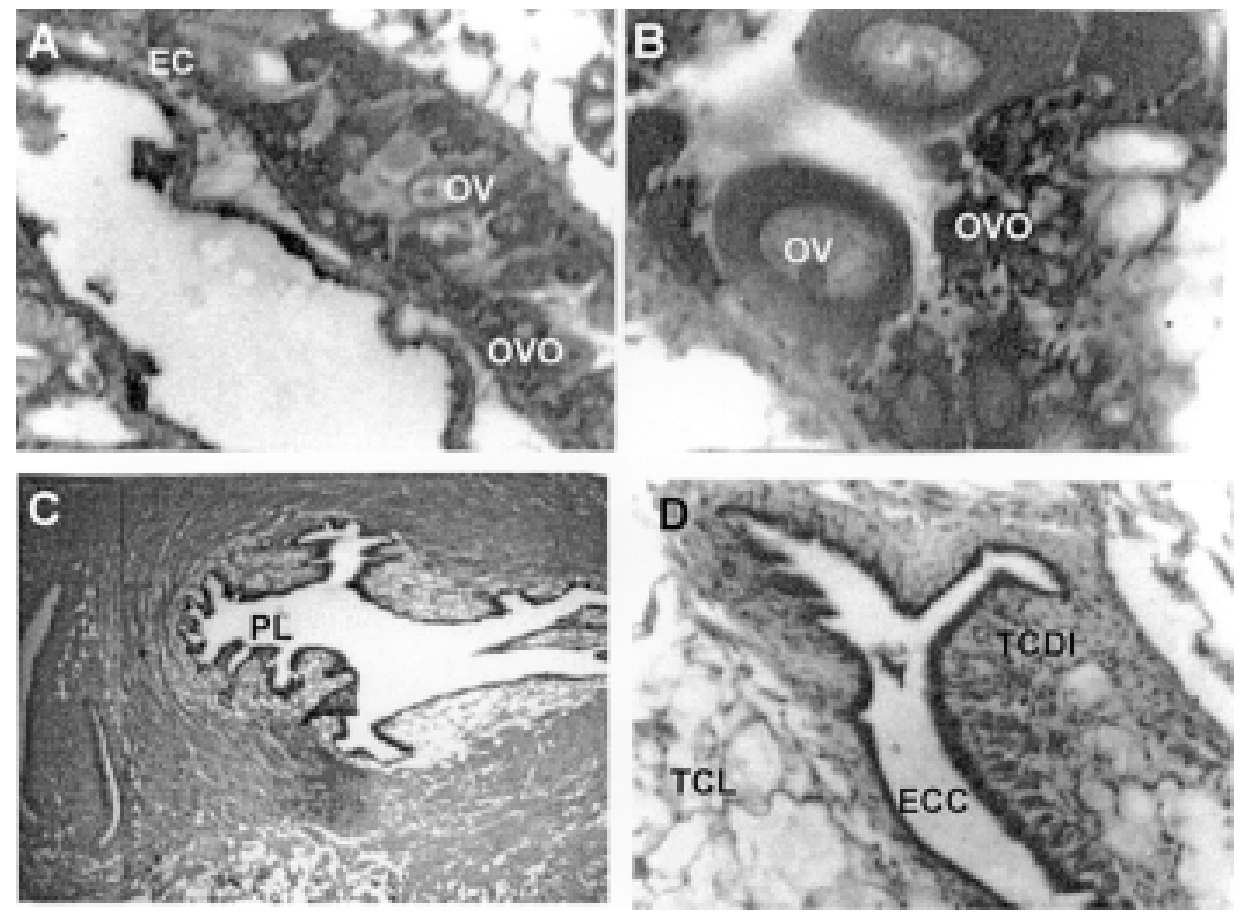

Fig. 10: Sistema reproductor femenino de P. patula catemacensis en etapa de maduración intermedia. (A) Ovario. El tamaño y número de ovogonias (OVO) aumenta y se aprecian algunos ovocitos maduros (OV) abajo del epitelio cilíndrico (EC) del ovario; H-E, 20x. (B) Ovocitos maduros (OV) y ovogonias (OVO) en mayor proporción; H-E, 40x. (C) Bolsa copulatriz. Conducto principal con pliegues (PL); H-E, 20x. (D) Oviducto, epitelio cilíndrico simple ciliado (ECC), tejido conjuntivo denso irregular (TCDI) y tejido conjuntivo laxo (TCL); H-E, 20x.

Female reproductive system of $P$. patula catemacensis in intermediate maturation stage. (A) Ovary. The number and the size of oogonia $(\mathrm{OVO})$ increases, and some mature oocytes $(\mathrm{OV})$ can be observed below the columnar epithelium (EC) of the ovary; H-E, 20x. (B) Mature oocytes (OV) and oogonia (OVO) in increasing proportion; H-E, 40x. (C) Bursa copulatrix. Folds in the main conduct (PL); H-E, 20x. (D) Oviduct, simple ciliated columnar epithelium (ECC), dense irregular connective tissue (TCDI), and loose connective tissue (TCL); H-E, 20x.
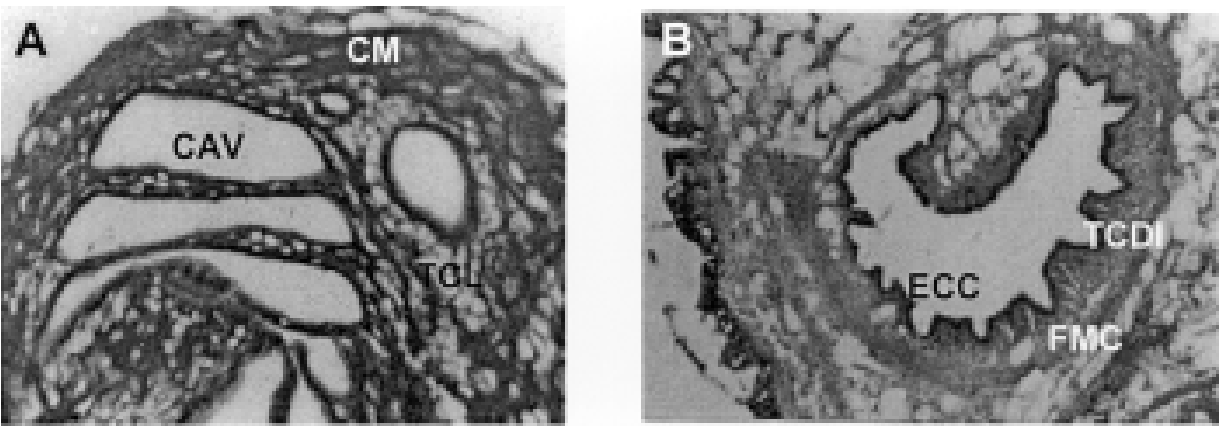

Fig. 11: Sistema reproductor femenino de P. patula catemacensis en etapa de madurez total. (A) Bolsa copulatriz, formada por cavidades de paredes delgadas (CAV), tejido conjuntivo laxo (TCL) y capa muscular (CM); H-E, 20x. (B) Gonoporo cubierto por epitelio cilíndrico simple ciliado (ECC), tejido conjuntivo laxo (TCL), tejido conjuntivo denso irregular (TCDI) y fibras musculares circulares (FMC); H-E, 20x.

Female reproductive system of $P$. patula catemacensis in full maturity phase. (A) Bursa copulatrix with cavities of thin walls (CAV), loose connective tissue (TCL), and muscular layer (CM); H-E, 20x. (B) Gonopore lined with simple ciliated columnar tissue (ECC), loose connective tissue (TCL), dense irregular connective tissue (TCDI) and circular -muscular fibers (FMC); H-E, 20x. 
TABLA 2

Edad, peso y talla correspondientes a las etapas de madurez gonádica de las hembras de Pomacea patula catemacensis identificadas en el estudio histológico. Valores promedio e intervalo de confianza (95\%)

Age, weight and size corresponding to the stages of gonadic maturity, established in the histological study in females of Pomacea patula catemacensis. Average values and confidence intervals (95\%)

\begin{tabular}{crrl}
\hline $\begin{array}{c}\text { Edad } \\
\text { (meses })\end{array}$ & \multicolumn{1}{c}{$\begin{array}{c}\text { Peso } \\
(\mathrm{g})\end{array}$} & \multicolumn{1}{c}{$\begin{array}{c}\text { Talla } \\
(\mathrm{mm})\end{array}$} & Etapa de madurez \\
\hline 0 & $0,0075 \pm 0,001$ & $1 \pm 0,28$ & Inmadura o indiferenciada \\
1 & $0,11 \pm 0,005$ & $4,52 \pm 2,5$ & Inmadura o indiferenciada \\
2 & $0,19 \pm 0,048$ & $9 \pm 1,92$ & Inmadura o indiferenciada \\
3 & $1,39 \pm 0,21$ & $18,95 \pm 1,95$ & Maduración temprana \\
4 & $2,27 \pm 0,21$ & $29,29 \pm 4,89$ & Maduración intermedia \\
5 & $6,47 \pm 1,03$ & $31,5 \pm 1,2$ & Maduración intermedia \\
6 & $12,25 \pm 2,54$ & $33,5 \pm 3,92$ & Madurez total \\
\hline
\end{tabular}

mente por Andrews (1964), quien encontró que el aparato reproductor masculino presenta una vaina del pene en lugar de un órgano copulador como el observado en nuestro estudio. El epitelio del conducto seminal no cambia, por lo que no es tan fácil distinguir un vaso eferente y uno deferente, distinguiéndose solo por la posición anatómica. La organización de la próstata de $P$. patula catemacensis coincide con la de $P$. canaliculata, ya que presenta el mismo epitelio cilíndrico ciliado y las células glandulares subepiteliales en forma de botella que desembocan en el conducto de la próstata, y solo difieren en la presencia de la capa muscular que rodea el epitelio en $P$. canaliculata. En el aparato reproductor femenino, el ovario es una estructura alargada única que rodea a la columela en la zona interna de la glándula digestiva, por lo que difiere del ovario racimoso que se reporta para P. flagellata (Rancel-Ruiz 1987), P. canaliculata (Lopes 1956b, Andrews 1964) у $P$. lineata (Lopes 1956a).

El órgano que presentó más diferencias fue la glándula de la albúmina. Andrews (1964) reporta para $P$. canaliculata la existencia de una bolsa copulatriz y un receptáculo seminal en los cuales desemboca el oviducto, el cual se encuentra enrollado en sí mismo dentro de la glándula de la albúmina; por su parte Vermeire \& Hinsch (1984) reportan el mismo arreglo en $P$. paludosa. En $P$. patula catemacensis se realizaron cortes seriados para seguir el conducto a lo largo de toda la glándula, sin lograr encontrar dicha zona, aunque sí se observó la transición del conducto de la glándula para formar la bolsa copulatriz conforme va perdiendo las glándulas intraepiteliales. La producción de carbonato de calcio se lleva a cabo en la glándula de la albúmina, donde se encontraron célu- las con vesículas de carbonato de calcio, en forma inestable como los cristales que observaron Meenakshi et al. (1974) en esa región, de tal manera que no se interrumpe el paso de los espermatozoides hasta el ovocito maduro en la bolsa copulatriz. Se observó que cuando son ovipositados, los huevos tienen consistencia gelatinosa y el corión se solidifica cuando entra en contacto con el oxígeno del aire.

En 1888 Bouvier (citado en Andrews 1964) había considerado la presencia de un pene rudimentario en las hembras de algunos Ampullariidae, como vestigio de hermafroditismo ancestral, aunque esa característica solo la observó en organismos maduros, pero en $P$. patula catemacensis no encontramos anatómicamente esta estructura y desde el punto de vista histológico comprobamos que los organismos son estrictamente dioicos. Adicionalmente, al hacer el estudio de los juveniles de $P$. patula catemacensis se observó que no hay precursores o vestigios de una condición hermafrodita en ninguna parte del sistema reproductor.

El inicio de la diferenciación gonádica (etapa en la que se distinguen machos y hembras solo histológicamente) se observó a los tres meses al encontrar células germinales ubicadas en el ápice de la espira del cuerpo del caracol, las cuales constituyen el testículo o el ovario, sin presentar protandria ni protoginea. Esto último coincide con lo que Andrews (1964) encontró en $P$. canaliculata al analizar el desarrollo de su sistema reproductor.

El tejido precursor de la glándula de la albúmina en las hembras aparece cuando se alcanza la talla de 29,29 $\pm 4,9 \mathrm{~mm}$, a los cuatro meses de edad, pero comienza a madurar hasta la edad de cinco meses, al igual que la vaina del pene y el órgano copulador. Las glándulas subepitelia- 
les del conducto principal de la glándula de la albúmina tienen una función recepto-secretora (Hinsch \& Vermeire 1990a), de tal manera que pueden ser estimuladas por las hormonas gonádicas, ya que con la técnica Tricrómica de Masson se determinó que producen una secreción de naturaleza proteica, que puede estimular la producción de albúmina y carbonato de calcio; esto explicaría el porqué la glándula de la albúmina madura hasta el final.

La madurez total se alcanzó a los seis meses de edad en ambos sexos, la hembra a los 33,5 \pm $3,92 \mathrm{~mm}$ y el macho a los $38 \pm 3,56 \mathrm{~mm}$. Por lo anterior se puede proponer a la talla de primera madurez gonádica $(40 \mathrm{~mm})$ como la mínima legal de captura, como una medida de protección que puede contribuir a un manejo más racional del recurso pesquero. Adicionalmente, se pueden tomar en cuenta como indicadores de madurez gonádica apreciables a simple vista, la coloración naranja de la glándula de la albúmina en las hembras, y la coloración rosa brillante que corresponde al órgano copulador en los machos. El considerar la talla mínima de captura según lo sugerido, es un punto que amerita atención inmediata, pues en análisis morfométricos no publicados de muestras de la captura comercial, se ha encontrado que la talla de por lo menos el $28 \%$ de los organismos oscila entre 26 y $36 \mathrm{~mm}$, lo que permite suponer que se podría estar impactando negativamente a la población, al retirar a individuos que aún no maduran o que están en proceso de maduración.

\section{AGRADECIMIENTOS}

Este estudio fue financiado por la Coordinación General de Posgrado e Investigación (CGPI) del I. P. N. Los autores agradecen a los sistemas COFAA-IPN y EDI-IPN por los apoyos otorgados.

\section{LITERATURA CITADA}

ANDREWS EB (1964) The functional anatomy and histology of the reproductive system of some Pilid Gastropods molluscs. Proceedings of the Malacological Society (London) 36: 121-139.

ESPINOSA-CHÁVEZ F, F MARTÍNEZ-JERÓNIMO \& $\mathrm{T}$ GUTIÉRREZ-CASTREJÓN (1992) Eficiencia comparativa de la capacidad nitrificante de filtros biológicos construidos con grava de sílice o tezontle. Revista Latinoamericana de Microbiología (México) 37: 109-119.

ESPINOSA-CHÁVEZ F \& FF MARTÍNEZ-JERÓNIMO (inédito) Crecimiento y fecundidad de $P$. patula (Gastropoda:Ampullariidae) alimentado con dietas gelificadas de Scenedesmus incrassatulus (Clorophyceae) y alimento balanceado para trucha. $25 \mathrm{pp}$.

GONZÁLEZ-SORIANO E, R DIRZO \& RC VOGT (1997) Historia natural de los Tuxtlas. Instituto de Biología, Universidad Nacional Autónoma de MéxicoCONABIO, México. 647 pp.

GOMOT L \& A DERAY (1986) Los caracoles. Mundo Científico (México) 69: 478-489.

HINSCH GW \& PE VERMEIRE (1990a) Histochemistry and Ultrastructure of the Albumen Gland Duct of the Prosobranch Gastropod Pomacea paludosa. Invertebrate Reproduction and Development 17: 213-219.

HINSCH GW \& PE VERMEIRE (1990b) Histochemistry and ultrastructure of the capsule gland duct of the Prosobranch gastropod Pomacea paludosa. Invertebrate Reproduction and Development 17: 203-211.

LOPES HS (1955) Sobre duas espécies do genero "Pomacea" Perry, com un estudo da genitália em ambos os sexos (Mesogastropoda, Architaenoglossa, Mollusca). Revista Brasileira do Biología (Brasil) 15:203-210.

LOPES HS (1956a) Sobre "Pomacea lineata" (Spix, 1827) (Mesogastropoda, Architaenoglossa, Mollusca). Revista Brasileira do Biología (Brasil) 16: 375-380.

LOPES HS (1956b) Sobre "Pomacea canaliculata" (Spix, 1827) (Mesogastropoda, Architaenoglossa, Mollusca). Revista Brasileira do Biología (Brasil) 16: 535-542.

MARTÍNEZ-JERÓNIMO FF \& F ESPINOSA-CHÁVEZ (1994) A laboratory-scale system for mass culture of freshwater microalgae in polyethylene bags. Journal of Applied Phycology 6: 423-425.

MEENAKSHI VR, PL BLACKWELDER \& HH BOER (1974) Studies on the formation of calcified eggcapsules of Ampullarid snails. I. Vaterite crystals in the reproductive system and the egg capsules of Pomacea paludosa. Calcified Tissue Research 16: 283-281.

NARANJO-GARCÍA E \& F GARCÍA-CUBAS (1985) Algunas consideraciones sobre el género Pomacea (Gastropoda. Pilidae) en México y Centroamérica. Anales del Instituto de Biología, Universidad Nacional Autónoma de México, Serie Zoología (México) 56: 603-606.

OSORIO-SANTAMARÍA M \& HE GARCÍA Y GARCÍA (1987) Aspectos reproductivos del caracol de agua dulce (Pomacea patula catemacensis) con observaciones en laboratorio y campo. Tesis Profesional, Universidad Veracruzana, Jalapa, Veracruz, México. 53 pp.

RANGEL-RUIZ LS (1987) Estudio morfológico de Pomacea flagellata (Say, 1827) (Gastropoda: Ampullariidae) y algunas consideraciones sobre su taxonomía y distribución geográfica en México. Anales del Instituto de Biología. Universidad Nacional Autónoma de México, Serie Zoología (México) 58: 21-34

STEIN JR (1973) Handbook of phycological methods. Culture methods and growth measurements. Cambridge University Press, London, United Kingdom. Xx pp.

VERMEIRE PE \& GW HINSCH (1984) Structure of the female reproductive tract of the apple snail. II. Scanning Electron Microscopy. Tissue and Cell 16: 107-114. 